\title{
Faktor-Faktor Customer Experience Management yang Berpengaruh terhadap Peningkatan Citra Telkom Speedy pada PT TELKOM Kandatel Bekasi
}

\author{
Aurora Nadhia \\ Alumni Departemen Manajemen, Fakultas Ekonomi dan Manajemen \\ Institut Pertanian Bogor \\ Musa Hubeis \\ Departemen Manajemen, Fakultas Ekonomi dan Manajemen \\ Institut Pertanian Bogor \\ Email: hubeis.musa@yahoo.com
}

\begin{abstract}
Speedy as PT. Telkom Product is facing a high competition in internet services provider business. The product functional value is not sufficient to win the competition but it is need the internet service image as product image. Nowadays, Consumer perspective about product image is determined by their experiences. This is the reason behind Customer Experience Management (CEM) which defines as a process of managing customer experiences through company products or services. The factors of CEM are product, service, channel, promotion and brand. The research objectives at PT. Telkom Kandatel Bekasi are (1) to identify CEM factors of SPEEDY (2) to identify which CEM factors are influencing product image, (3) to indentify dominant CEM factor which influencing product imager (4) to recommend the effective implementation of CEM. The research showed 68,8 percent CEM factors were influencing Telkom Speedy image, which there are three factors e.g. product, promotion and brand were partially influenced Telkom Speedy image. Product was the most dominant factors of CEM which influenced image. The research recommended PT. Telkom to improve the quality of Telkom Speedy through speed of internet access improvement, front liners services, and promotion, to manage customer experience.
\end{abstract}

Key words: Internet Services, CEM, image, experience, Telkom Speedy

\section{Pendahuluan}

Persaingan terjadi bila terdapat produk yang sama dari beberapa produsen berbeda sedang memperebutkan pasar sama. Persaingan dapat ditemukan di berbagai bentuk bisnis, termasuk di dalam industri telekomunikasi. Telekomunikasi saat ini tidak hanya dilakukan melalui saluran telepon, tetapi juga dapat menggunakan jaringan internet. Hal ini menuntut perusahaan-perusahaan penyedia jasa layanan telekomunikasi menjadi semakin kreatif dan inovatif dalam mengikuti perkembangan zaman.

Bisnis telekomunikasi yang dulu dimonopoli PT TELKOM, kini harus dibagi dan diperebutkan oleh berbagai perusahaan di bidang yang sama. Lima (5) perusahaan terbesar seperti Telkomsel (Simpati, Halo, As dan Telkomsel Flash), Indosat (IM3, IM2 dan Mentari), Excelcomindo (XL), Bakrie Telecom (Esia) dan Mobile-8 (Fren dan Mobi). 
Hal ini menuntut PT TELKOM untuk terus mengembangkan produk dan meningkatkan mutu layanan terhadap pelanggan untuk tetap bertahan di tengah persaingan. Produk yang dimiliki oleh PT TELKOM selain jaringan telepon rumah adalah telepon berteknologi Code Division Multiple Access (CDMA) seperti TELKOM Flexi dan produk untuk akses internet rumah seperti TELKOM Speedy.

Seiring dengan berkembangnya teknologi internet, perusahaan-perusahaan penyedia jasa layanan internet, termasuk PT TELKOM terus berusaha meningkatkan pangsa pasar dan penjualannya. Berdasarkan data statistik pengguna internet dari APIII (2009), diketahui bahwa pengguna internet di Indonesia terus bertambah secara nyata setiap tahunnya (Tabel 1 ).

Kuartal IV pada tahun 2009, layanan internet TELKOM Speedy terus tumbuh secara cukup meyakinkan dengan angka pertumbuhan $65 \%$ dibandingkan periode pada tahun sebelumnya. Pencapaian tersebut memposisikan internet cepat Speedy sebagai market leader layanan fixed broadband di Indonesia. Kuartal III pada tahun 2009, jumlah pelanggan Speedy sudah mendekati angka satu juta pelanggan (Telkom, 2009).

Tabel 1. Jumlah Pengguna dan Pelanggan internet di Indonesia

\begin{tabular}{ccc}
\hline Tahun & $\begin{array}{c}\text { Jumlah Pengguna (Orang) } \\
\text { (Orang) }\end{array}$ & $\begin{array}{c}\text { Jumlah Pelanggan } \\
\text { (Ong }\end{array}$ \\
1999 & 512.000 & 134.000 \\
2000 & 1.000 .000 & 256.000 \\
2001 & 1.900 .000 & 400.000 \\
2002 & 4.200 .000 & 581.000 \\
2003 & 4.500 .000 & 667.002 \\
2004 & 8.000 .534 & 865.706 \\
2005 & 11.226 .143 & 1.087 .428 \\
2006 & 16.000 .000 & 1.500 .000 \\
2007 & 20.000 .000 & 1.700 .000 \\
2008 & 25.000 .000 & 2.000 .000 \\
\hline
\end{tabular}

Sumber : APIII, 2009

Di tengah maraknya persaingan, citra produk yang dipasarkan menjadi penting bagi perusahaan, karena memiliki jaminan mutu produk maupun layanan pada saat pembelian dan layanan purna jual. Menurut Kotler and Keller (2006), citra adalah cara masyarakat mempersepsi (memikirkan) perusahaan atau produknya. Citra juga merupakan seperangkat keyakinan, ide dan kesan yang dimiliki seseorang terhadap suatu obyek. Sikap dan tindakan orang terhadap obyek sangat ditentukan oleh citra obyek tersebut. Pendapat tersebut menunjukkan bahwa, sikap dan perilaku pelanggan ter-hadap produk dapat dipengaruhi oleh citra produk tersebut di mata pelanggan, yaitu semakin baik citra produk, maka pelanggan akan bersikap dan berperilaku positif terhadap produk.

Citra merupakan dampak dari bauran promosi dan pengalaman pelanggan dengan suatu produk untuk mempengaruhi persepsi dan pikiran pelanggan terhadap apa yang ditawarkan oleh produk tersebut. Citra di mata publik dapat terlihat dari pendapat atau pola pikir pada saat mempersepsikan realitas yang terjadi. Realitas didapatkan dari media massa atau media-media lain yang berpengaruh langsung dengan publik. 
Dengan begitu, hal yang perlu dipahami sehubungan dengan terbentuknya citra adalah adanya persepsi (Wasesa, 2006).

Salah satu cara meningkatkan citra produk adalah turut melibatkan pengalaman konsumen dalam menggunakan produk. Demi mendekati, mendapatkan dan mempertahankan konsumen, maka produsen melalui produknya perlu menghadirkan pengalaman-pengalaman yang mengesankan bagi konsumen agar mau menggunakan produknya. Salah satu cara mengatur pengalaman konsumen dengan Customer Experience Management (CEM). Faktor-faktor yang menjadi bagian CEM adalah product, service, channel, promotion dan brand. Jika faktor-faktor tersebut dikelola dengan baik maka menghasilkan pengalaman mengesankan bagi konsumen yang berpengaruh terhadap citra produk di matanya dan nantinya berdampak pada kepuasan dan loyalitas konsumen, serta peningkatan penjualan produk.

PT TELKOM merupakan perusahaan telekomunikasi terbesar di Indonesia yang dewasa ini tidak hanya melayani layanan telepon rumah, tetapi juga layanan telepon CDMA dan layanan akses internet. Dengan semakin berkembangnya teknologi internet, PT TELKOM harus mampu bersaing dengan pesaingnya dari berbagai perusahaan penyedia jasa layanan telekomunikasi dan internet, yaitu meningkatkan citra produk dan menarik konsumen melakukan pembelian terhadap produknya untuk meningkatkan penjualan dan akhirnya profitabilitas perusahaan.

Schmitt (2003), mengemukakan bahwa CEM merupakan proses untuk mengatur keseluruhan pengalaman pelanggan (fokus) dengan produk atau perusahaan secara strategik. Dalam hal ini CEM berhubungan dengan pelanggan pada setiap hal-hal kecil dan memberikan unsur-unsur berbeda pada pengalaman pelanggan.

Berdasarkan permasalahan di atas, dapat disusun rumusan masalah berikut :

1. Bagaimana penerapan faktor-faktor CEM Telkom Speedy di PT TELKOM Kandatel Bekasi?

2. Bagaimana pengaruh dari faktor-faktor CEM terhadap citra produk akses internet TELKOM Speedy?

3. Peubah CEM apakah yang paling berpengaruh terhadap citra produk TELKOM Speedy?

4. Bagaimana menerapkan CEM efektif untuk PT TELKOM Kandatel Bekasi ? Adapun tujuan dari penelitian ini adalah :

1. Mempelajari faktor-faktor CEM Telkom Speedy di PT TELKOM Kandatel Bekasi.

2. Menganalisis pengaruh dari faktor-faktor CEM terhadap citra TELKOM Speedy.

3. Menganalisis peubah CEM yang berpengaruh dominan terhadap citra TELKOM Speedy.

4. Merekomendasikan strategi penerapan CEM yang efektif untuk PT TELKOM Kandatel Bekasi.

\section{Metode Penelitian}

Kajian penelitian ini berfokus pada salah satu produk dari PT TELKOM yang memberikan pelayanan untuk akses internet, yaitu TELKOM Speedy. Dalam hal ini ingin diketahui seberapa besar pengaruh CEM terhadap citra produk TELKOM Speedy, yang meliputi faktor-faktor seperti product, service, brand, promotion dan channel yang diidentifikasi melalui kuesioner kepada pelanggan. 
Hasil yang didapatkan setelah proses analisis diharapkan dapat menjadi masukan bagi perusahaan dalam memberikan kepuasan pada pelanggan dan berdampak pada peningkatan citra Telkom Speedy. Kerangka pemikiran penelitian dapat dilihat pada Gambar 1.

Penelitian dilakukan di PT Telkom Kandatel Bekasi, Jalan Raya Tembaga Nomor 4, Rawa Tembaga, Bekasi dan Plasa TELKOM Bekasi Ruko KCC Nomor 3-5, Bekasi selama tiga (3) bulan, yaitu bulan Desember 2009 - Maret 2010.

Jenis data dalam penelitian ini adalah data primer dan sekunder. Data primer didapatkan melalui wawancara, kuesioner dan observasi. Metode penarikan contoh dilakukan dengan teknik convenience sampling. Data sekunder diperoleh dari studi literatur melalui buku, data perusahaan, internet dan data publikasi lainnya.

Uji validitas menunjukkan sejauh mana suatu alat pengukur mengukur apa yang ingin diukur (Umar, 2002). Uji ini digunakan untuk mengetahui kelayakan butir-butir dalam suatu daftar pertanyaan dalam mendefinisikan suatu peubah. Uji validitas dilakukan dengan menggunakan teknik korelasi product moment dengan rumus :

$$
r=\frac{n \sum X Y-\left(\sum X \sum Y\right)}{\left[n \sum X^{2}-\left(\sum X\right)^{2}\right]\left[n \sum Y^{2}-\left(\sum Y\right)^{2}\right]}
$$

Keterangan :

$r=$ Nilai koefisien korelasi

$\mathrm{n}=$ Jumlah responden

$\mathrm{X}=$ Skor masing-masing pertanyaan

$\mathrm{Y}=$ Skor total

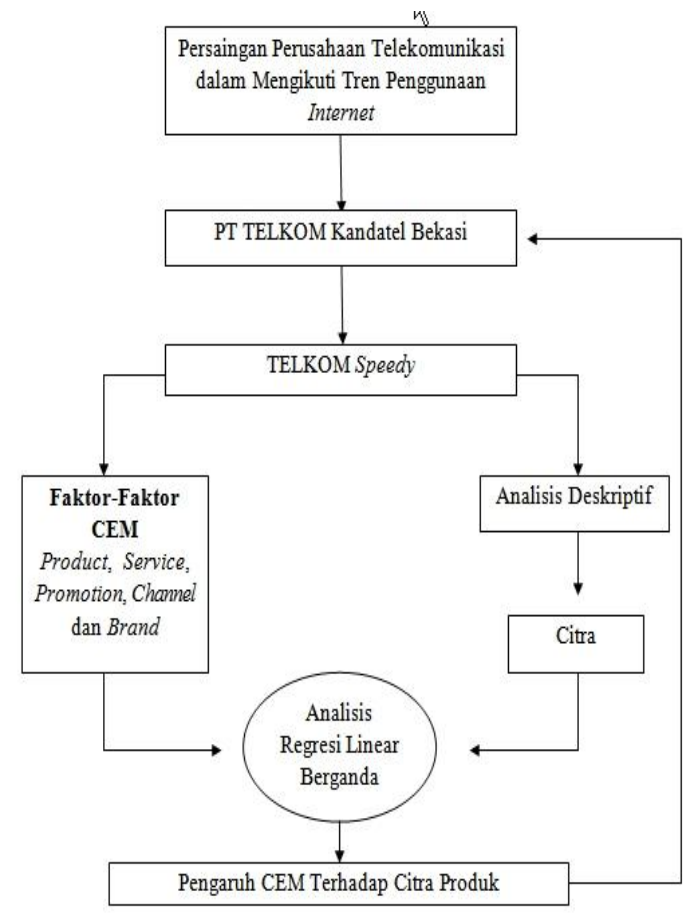

Gambar 1. Kerangka Pemikiran Penelitian 
Reliabilitas adalah suatu nilai yang menunjukkan konsistensi suatu alat ukur (misal, reesponden) dalam mengukur gejala missal, pertanyaan) yang sama (Umar, 2002). Uji ini dilakukan untuk mengetahui keandalan kuesioner.

Reliabilitas suatu konstruk peubah di-katakan baik, jika memiliki nilai Cronbach's Alpha $>0,60$ (Nugroho, 2005). Pengujian reliabilitas menggunakan teknik Cronbach dengan program SPSS, dengan rumus berikut :

$$
\mathrm{r}_{11}=\frac{\mathrm{k}}{\mathrm{k}-1} \quad 1-\frac{\sum\left(\sigma_{\mathrm{b}}\right)^{2}}{\left(\sigma_{\mathrm{t}}\right)^{2}}
$$

Keterangan :

$$
\begin{array}{ll}
\mathrm{r}_{11} & =\text { reliabilitas instrumen } \\
\mathrm{k} & =\text { banyak butir pertanyaan } \\
\sum\left(\sigma_{b}\right)^{2} & =\text { jumlah ragam butir } \\
\left(\sigma_{t}\right)^{2} & =\text { ragam total }
\end{array}
$$

Rumus ragam yang digunakan :

$$
\sigma^{2}=\frac{\sum\left(X_{1}\right)^{2}-\frac{\left(\sum X_{1}\right)^{2}}{n}}{n}
$$

Di mana :

$\mathrm{n} \quad=$ jumlah responden

$\mathrm{X}_{\mathrm{i}} \quad$ = skor masing-masing pertanyaan

untuk obyek ke-i

Model regresi linear berganda disebut model yang baik, jika model tersebut bebas dari asumsi klasik statistik (Nugroho, 2005). Proses pengujian asumsi klasik statistik dilakukan bersama-sama dengan proses uji regresi, sehingga langkah-langkah dan media kotak kerja yang digunakan sama dengan uji regresi SPSS.

Uji multikolinearitas diperlukan untuk mengetahui ada tidaknya peubah independen yang memiliki kemiripan dengan peubah independen lain dalam suatu model, karena dapat menyebabkan korelasi yang sangat kuat antara suatu peubah independen dengan peubah independen yang lainnya. Selain itu, bertujuan menghindari kebiasan dalam proses pengambilan keputusan mengenai pengaruh pada uji parsial masing-masing peubah independen terhadap peubah dependen (Nugroho, 2005).

Uji heteroskedastisitas diperlukan untuk mengetahui apakah terdapat pengaruh yang sistematis antara peubah yang diidentifikasi dengan residual absolutnya melalui pola gambar scatterplot dari model regresi yang didapatkan (Nugroho, 2005).

Regresi bertujuan menguji pengaruh antara satu peubah terhadap peubah lainnya. Peubah yang dipengaruhi disebut peubah tergantung atau dependen, sedangkan peubah yang mempengaruhi disebut peubah bebas atau peubah independen (Umar, 2002). Dalam regresi berganda, persamaan regresi mempunyai lebih dari satu peubah independen.

Dalam penelitian ini, peubah dependen yang dimaksud adalah citra TELKOM Speedy dan peubah-peubah independen adalah product, service, channel, promotion dan brand dengan rumusnya :

$$
\hat{Y}=a+b_{1} X_{1}+b_{2} X_{2}+b_{3} X_{3}+b_{4} X_{4}+b_{5} X_{5}
$$


Di mana :

$\hat{Y}=$ citra produk TELKOM Speedy

$\mathrm{X}_{1}=$ product

$\mathrm{X}_{2}=$ service

$\mathrm{X}_{3}=$ channel

$\mathrm{X}_{4}=$ promotion

$\mathrm{x}_{5}=$ brand

$a=$ konstanta $b_{1}, b_{2}, b_{3}, b_{4}, b_{5}=$ koefisien regresi

Formulasi di atas diolah dengan software SPSS versi 16 untuk mendapatkan hasil dari pengaruh peubah independen terhadap peubah dependen, yaitu peubah CEM yang memberi pengaruh paling besar terhadap citra produk Speedy.

Uji simultan dengan uji $\mathrm{F}$ bertujuan mengetahui pengaruh bersama-sama peubah independen terhadap peubah dependen (Nugroho, 2005). Sedangkan uji t bertujuan mengetahui besarnya pengaruh masing-masing peubah independen secara individual terhadap peubah dependen. Uji t biasa disebut uji pengaruh secara parsial, karena dapat melihat pengaruh satu (1) peubah independen terhadap peubah dependennya sementara peubah independen lainnya dalam keadaan tetap.

Uji $\mathrm{F}$ diketahui dengan melihat nilai nyata $\mathrm{F}$ apakah lebih besar dari alpha yang ditetapkan atau tidak serta uji t dilakukan dengan melihat nyatanya $\mathrm{t}$ hitung yang diperoleh dan dibandingkan dengan alpha yang ditetapkan.

\section{Hasil Penelitian}

III. 1. Faktor-Faktor CEM TELKOM Speedy pada PT TELKOM kandatel Bekasi Product

Produk Speedy tersedia dalam berbagai pilihan paket layanan sesuai kebutuhan di rumah maupun bisnis, baik paket jenis time based maupun unlimited dengan pilihan kecepatan bervariasi adalah :

a. Paket Mail (Limited 15 Jam 1 Mbps)

Paket ini ditujukan untuk pengenal-an internet atau pengguna yang jarang menggunakan internet, tetapi menginginkan koneksi yang cepat. Paket ini menawarkan kecepatan 1 Mbps downstream dan 256 kbps upstream dengan harga murah.

b. Paket Chat (Limited 50 Jam 1 Mbps)

Dengan menggunakan Paket Chat, pelanggan dapat melakukan koneksi internet kecepatan tinggi, durasi waktu lebih lama dan harga terjangkau. Kecepatan yang ditawarkan 1 Mbps downstream dan 256 kbps upstream.

c. Paket Family (Semi Unlimited 384 kbps)

Dengan kecepatan 384 kbps down-stream dan 96 kbps upstream tanpa batas waktu pelanggan dapat meng-akses internet sepuasnya untuk brows-ing maupun chatting selama masih dalam batas kuota 3 GB per bulan. Ketika kuota usage tercapai, kecepatan efektif akan diturunkan menjadi 128 kbps hingga akhir bulan dan kembali ke kecepatan semula pada bulan berikutnya.

d. Paket Load (Semi Unlimited 512 kbps)

Dengan kecepatan 512 kbps downstream dan 128 kbps upstream tanpa batas waktu pelanggan dapat mengakses internet sepuasnya untuk browsing lebih cepat, 
download, mau-pun chatting selama masih dalam batas kuota 3 GB per bulan. Ketika kuota usage tercapai, kecepatan efektif diturunkan menjadi 128 kbps hingga akhir bulan dan akan kembali ke cepatan semula pada bulan berikutnya.

e. Paket Game (Unlimited 1 Mbps)

Paket Game cocok untuk pelanggan profesional yang membutuhkan peng-gunaan internet secara share hingga ke-10 pengguna, dengan kecepatan $1 \mathrm{Mbps}$ downstream dan 256 kbps upstream, serta alokasi kapasitas ke gateway internasional lebih besar.

f. Paket Executive (Unlimited $2 \mathrm{Mbps}$ )

Paket Executive memiliki kecepatan 2 Mbps downstream dan 512 kbps upstream, serta alokasi kapasitas ke gateway internasional lebih besar. Pa-ket ini cocok untuk keperluan bisnis dan perkantoran dengan penggunaan internet secara share hingga ke20 pengguna.

g. Paket Biz (Unlimited 3 Mbps)

Dengan kecepatan 3 Mbps downstream dan 512 kbps upstream, serta alokasi kapasitas ke gateway internasional lebih besar cocok untuk keperluan bisnis dan perkantoran dengan penggunaan internet secara share hingga ke-30 pengguna.

h. Speedy Prepaid

Speedy Prepaid merupakan paket Speedy berbentuk kartu prabayar untuk melakukan koneksi internet. Paket ini cocok untuk pengguna dengan mobilitas tinggi dan dapat digunakan di line Speedy maupun TELKOM Hotspot di seluruh Indonesia. Kartu Speedy Prepaid tersedia dalam bentuk starter pack dengan nominal Rp 55.000.

\section{2. Service}

Pelayanan yang diberikan oleh PT TELKOM untuk pelanggan Speedy, dapat berupa pelayanan untuk pemberian informasi dan registrasi, instalasi produk, pelayanan gangguan, penanganan keluhan dan pemutusan. Semua pelayanan ini dapat diperoleh pelanggan di kantor pelayanan atau Plasa TELKOM.

\section{a. Customer Information}

Perusahaan dapat memberikan infor-masi kepada konsumen secara jelas, benar dan disampaikan dengan cara yang baik. Hal ini dapat dilakukan oleh semua pihak di dalam perusahaan, baik security, frontliners (customer service dan teller), manajer dan pihakpihak yang ber-hubungan langsung dengan konsumen.

\section{b. Customer Service dan Employee Behaviour}

Sikap dan perilaku karyawan per-usahaan dalam memberikan pelayanan pada pelanggan dapat dipengaruhi oleh pengalaman karyawan itu sendiri di dalam perusahaan, maka PT TELKOM memberikan suasana kerja kondusif dan memperlakukan karyawan sesuai dengan budaya organisasi perusahaan, sehingga melekat pada diri karyawan dan tentunya berdampak pada mutu pelayanan bagi pelanggan, disamping pemberian train-ing ditahap awal kerja.

c. Maintenance Service

Maintenance Service dilakukan perusahaan untuk menjaga mutu produk. Hal ini dapat dilihat dari pelayanan bila terjadi gangguan pada produk Speedy, seperti ketika Speedy 
tidak dapat digunakan untuk mengakses internet. Dalam hal maintenance dan performance, PT TELKOM memiliki divisi tersendiri yaitu Access Network Operational (ANO) dan Access Network Maintenance (ANM).

\section{d. Website Company}

Selain website perusahaan, PT TELKOM memiliki website tersendiri bagi TELKOM Speedy untuk memudahkan akses pelanggan terhadap informasi tentang produk Speedy, mendapatkan layanan-layanan lain seperti games, berita, chatting dan bergabung dengan komunitas Telkom Speedy.

\section{3. Channel}

Pelanggan dapat memperoleh Speedy dengan mendatangi Plasa TELKOM terdekat. Keberadaan Plasa TELKOM juga mempengaruhi kemudahan pelanggan untuk menjangkau tempat pelayanan, yaitu melakukan proses pembelian, pencarian informasi dan menyampaikan keluhan terhadap produk.

PT TELKOM menggunakan direct channel dalam menjual produknya kepada pelanggan, yaitu melayani seluruh proses di kantor pelayanan atau Plasa TELKOM. TELKOM juga memberikan kemudahan bagi pelanggan untuk melakukan proses pembayaran seperti melalui Anjungan Tunai Mandiri (ATM), Bank, Kantor Pos dan Plasa TELKOM.

\section{4. Promotion}

Promosi dapat dilakukan melalui dua (2) cara, yaitu above the line dan below the line. Pada promosi above the line, promosi dilakukan secara terpusat atau nasional, baik melalui media iklan televisi, poster, spanduk dan baliho yang sama untuk seluruh Indonesia. Sedangkan promosi secara below the line dilakukan sesuai kebutuhan masing-masing kantor daerah telekomunikasi yang tersebar di seluruh kota di Indonesia.

PT TELKOM Kandatel Bekasi, melakukan promosi berikut :

\section{a. Open Table dan Pameran}

Open Table merupakan kegiatan promosi berupa bazar Telkom Speedy. Pameran biasa dilakukan secara rutin di beberapa lokasi di kota Bekasi, yaitu, Bekasi Square, Bekasi Cyber Park, Grand Mall dan Mega Bekasi.

\section{b. Door to Door atau Personal Selling}

Dengan metode ini, perusahaan secara khusus mendatangi calon-calon pelanggan di rumah atau kantor untuk menawarkan produk Speedy.

c. Penyebaran Brosur

Penyebaran brosur dilakukan di tempat-tempat ramai dan berpotensi seperti di mall, restoran, perumahan, perkantoran, warung internet dan tempat wisata.

d. Kemitraan dengan Media di Bekasi

PT TELKOM Kandatel Bekasi melakukan kerjasama dengan mitra-mitra di Bekasi seperti radio dan media cetak. Promosi melalui radio yang dilakukan berupa Talk Show dan iklan. Radio yang menjadi mitra kerjasama PT TELKOM Kandatel Bekasi adalah, Gaya FM, Dakta FM, M2 Radio dan Radio Annisa. Sedangkan media cetak yang menjadi 
mitra PT TELKOM Bekasi adalah Harian Bekasi. Di dalam kemitraan dengan mediamedia yang ada, TELKOM Speedy menjadi sponsor dalam acara pelatihan internet, jaringan dan edukasi keunggulan teknologi Asymetric Digital Subscriber Line (ADSL). Kerjasama dengan media mendukung terbentuknya komunitas Telkom Speedy.

e. Kerja sama dengan Toko-Toko Komputer

Kerja sama dengan toko-toko kom-puter dilakukan memberikan pilihan paket-paket tertentu kepada pelanggan yang melakukan transaksi di toko computer, dengan cara member kupon diskon untuk pemasangan internet Speedy dan disatukan dengan promo pemasangan telepon rumah secara gratis. Promo ini juga hanya dibatasi pada pembelian produk-produk tertentu seperti laptop, komputer dan aksesoris lain sesuai dengan kesepakatan dengan pihak Telkom.

\section{f. Direct Mail}

Direct mail merupakan salah satu strategi pemasaran yang minim biaya dan menyentuh pelanggan secara per-sonal. Direct Mail dikirimkan oleh pihak TELKOM kepada calon pelanggan atau pelanggan tertentu melalui email untuk memberikan promosi dan informasi mengenai TELKOM Speedy.

\section{g. Merchandise}

Dalam berbagai event yang diselenggarakan oleh PT TELKOM Kandatel Bekasi, disediakan berbagai merchandise, seperti payung, mug, kaos dan lain-lain.

\section{5. Brand}

Merek merupakan bagian experience yang dirasakan pelangan. Pengalaman menarik ataupun buruk pelanggan terhadap suatu merek dapat mempengaruhi citra produk dari merek tersebut. Speedy merupakan merek layanan akses internet yang memberikan keunggulan dari sisi kecepatan akses dan Brand yang dapat menggiring harapan pelanggan.

Speedy berasal kata "speed", yang berarti kecepatan dan slogan "Speed That You Can Trust", atau tentunya pelanggan mengharapkan penggunaan produk tersebut memberikan mutu kecepatan dalam mengakses internet. Untuk membentuk karakteristik merek Speedy, dipertimbangkan empat (4) unsur penting, yaitu kesadaran konsumen pada merek Speedy, keuntungan yang dirasakan pelanggan dalam menggunakan merek Speedy, nilai yang diperoleh pelanggan dan pandangan pelanggan terhadap merek Speedy.

\section{6. Karakteristik Konsumen}

Penyebaran kuesioner dilakukan terhadap 100 orang konsumen TELKOM Speedy sesuai karakteristik seperti jenis kelamin, usia, pendapatan, pengeluaran untuk internet dan pendidikan. Berdasarkan karakteristik jenis kelamin, 100 konsumen TELKOM Speedy terdapat 51\% konsumen berjenis kelamin perempuan dan $49 \%$ berjenis kelamin laki-laki. Berdasarkan karaktersitik usia, diketahui sebagian besar konsumen (38\%) berusia 20-29 tahun dan dengan jumlah terendah berusia di bawah 20 tahun (5\%). 
Hasil penelitian juga menunjukkan sebagian besar konsumen (42\%) memiliki rataan penghasilan per bulan $\mathrm{Rp} 3.000 .001-6.000 .000$ dan yang terkecil rataan pendapatannya lebih besar dari Rp 9.000 .000 (8\%).

Sejumlah $50 \%$ konsumen memiliki rataan pengeluaran penggunaan internet dalam sebulan Rp 145.000-295.000, 38\% memiliki pengeluaran Rp 295.001-400.000 dan 12\% dengan pengeluaran $\mathrm{Rp} 75.000-145.000$. Mayoritas konsumen (25\%) bekerja sebagai pegawai negeri dan sebagai pensiunan $1 \%$. Berdasarkan tingkat pendidikan $49 \%$ konsumen berpendidikan sarjana dan hanya $1 \%$ berpendidikan Sekolah Dasar (SD).

\section{7. Perilaku pembelian}

Perilaku pembelian pelanggan TELKOM Speedy dibagi berdasarkan bagaimana cara pelanggan pertama kali mengenal, ketertarikan menggunakan, paket yang digunakan, lama waktu pelanggan menggunakan internet dalam satu bulan, provider lain yang digunakan dan lama waktu menjadi pelanggan TELKOM Speedy.

Dari 100 konsumen, mayoritas konsumen (33\%) pertama kali mengenal TELKOM Speedy melalui iklan. Berdasarkan ketertarikan konsumen untuk menggunakan TELKOM Speedy, 32\% konsumen tertarik karena kecepatan akses yang ditawarkan oleh pihak TELKOM.

Paket yang digunakan oleh konsumen didominasi oleh Paket Family (62\%). Hal ini dapat dilihat dari keuntungan yang diperoleh dengan menggunakan Paket Family, yaitu Rp 165.000-245.000 per bulan, dengan kuota internet semi unlimited untuk pemakaian skala kecil.

Dari 100 responden terdapat 50\% menggunakan internet selama 15-50 jam dalam satu bulan, 33\% menggunakan internet lebih lama dari 50 jam dalam satu bulan dan 16\% menggunakan internet dengan waktu kurang dari 15 jam dalam satu bulan.

Selain TELKOM Speedy, masih terdapat beberapa provider layanan internet mobil, baik milik PT TELKOM sendiri maupun perusahaan lain. Dalam hal ini diketahui $69 \%$ konsumen tidak menggunakan provider layanan internet selain TELKOM Speedy dan jumlah terkecil (2\%) menggunakan provider Three.

Hingga tahun 2009, PT TELKOM Kandatel Bekasi memiliki 56.000 pelanggan Speedy dengan berbagai variasi lama waktu berlangganan. Sejumlah $36 \%$ konsumen menjadi pelanggan selama jangka waktu 12-24 bulan dan 20\% menjadi pelanggan Speedy lebih lama dari 24 bulan.

III. 8. Analisis Regresi Linear Berganda : Pengaruh CEM Terhadap Citra TELKOM Speedy Hasil uji validitas dibandingkan dengan $r$ tabel bernilai 0,361 . Uji coba kuesioner dilakukan terhadap 30 kuesioner pertama dari responden yang berada di Plasa TELKOM. Dari uji ini didapatkan 24 pertanyaan valid.

Uji reliabilitas dilakukan dengan rumus Cronbach's Alpha. Dari hasil perhitungan 30 kuesioner pertama diperoleh hasil untuk uji reliabilitas 0,921. Reliabilitas suatu konstruk peubah dikatakan baik, jika memiliki nilai Cronbach's Alpha >0,60, maka kuesioner dapat diandalkan untuk dijadikan alat ukur pada penelitian ini. 


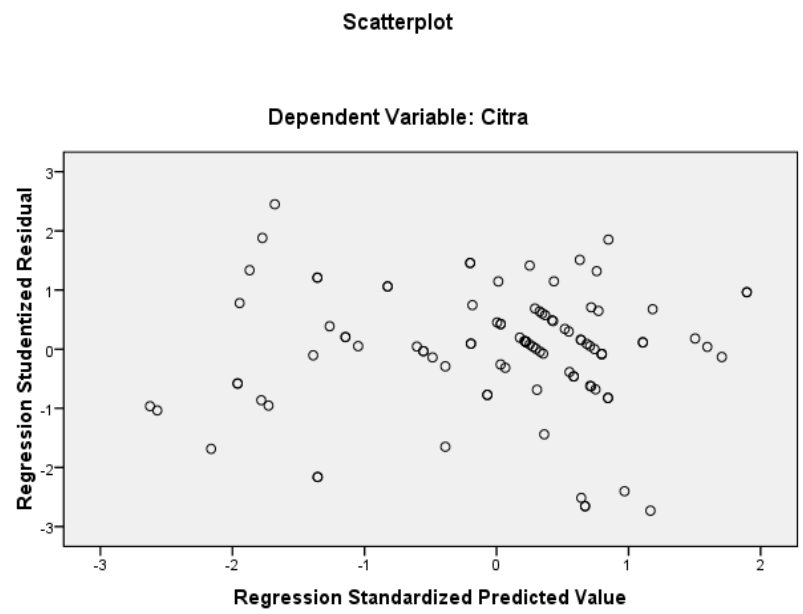

Gambar 2. Scatterplot

III. 9. Uji Asumsi Klasik

Model regresi linear berganda dapat disebut sebagai model yang baik, jika model tersebut bebas dari asumsi klasik statistic seperti multikolinearitas dan heteroskedastisitas. Dalam hal ini tidak dilakukan uji autokorelasi, karena data yang dipakai bukan bersifat time series ataupun cross section.

Deteksi multikolinearitas pada suatu model regresi linear berganda dapat dilihat dari nilai Variance Inflation Factor (VIF) tidak lebih dari 10 dan nilai Tolerance tidak kurang dari 0,1. Semakin tinggi VIF, maka semakin rendah Tolerance. Pada Tabel 4 dapat dilihat nilai VIF dan Tolerance pada masing-masing peubah independen, sehingga model regresi linear berganda terbebas dari asumsi klasik statistik multikolinearitas dan dapat digunakan dalam penelitian.

Tabel 4. Hasil Uji Multikolinearitas

\begin{tabular}{|c|c|c|c|}
\hline \multirow{2}{*}{ Peubah } & \multicolumn{2}{|c|}{ Collinearity Statistic } & \multirow{2}{*}{ Keterangan } \\
\hline & Tolerance & VIF & \\
\hline Product $\left(\mathrm{X}_{1}\right)$ & 0,507 & 1,971 & \multirow{5}{*}{$\begin{array}{c}\text { Tidak terjadi } \\
\text { multikolinearitas }\end{array}$} \\
\hline Service $\left(X_{2}\right)$ & 0,589 & 1,699 & \\
\hline Channel $\left(\mathrm{X}_{3}\right)$ & 0,581 & 1,722 & \\
\hline Promotion $\left(\mathrm{X}_{4}\right)$ & 0,396 & 2,522 & \\
\hline Brand $\left(\mathrm{X}_{5}\right)$ & 0,426 & 2,347 & \\
\hline
\end{tabular}

Analisis pada gambar Scatterplot menyatakan bahwa pada model regresi linear berganda tidak terdapat heteroskedastisitas karena titik-titik data menyebar di atas dan di bawah atau di sekitar angka 0 , titik-titik data tidak mengumpul di atas atau di bawah saja, penyebaran titik-titik data tidak membentuk pola bergelombang melebar dan menyempit. 


\section{10. Persamaan Regresi Linear Berganda}

Peubah independen pada penelitian ini terdiri dari product, service, channel, brand dan promotion. Sedangkan peubah dependen adalah citra. Untuk mengetahui seberapa besar kemampuan peubah independen men-jelaskan peubah dependen pada regresi linear berganda dapat dilihat dari nilai Adjusted $R$ Square. Pada penelitian ini didapatkan Adjusted $R$ Square 0,688 , artinya $68,8 \%$ peubah dependen citra Telkom Speedy dapat dijelaskan oleh peubah independen CEM dan sisanya $(31,2 \%)$ dijelaskan oleh peubah lain diluar peubah yang digunakan, maka model regresi linear berganda layak dipakai.

Data yang digunakan untuk membuat persamaan regresi adalah besaran koefisien regresi pada kolom Unstandardized Coefficient pada tabel Coefficient $\beta$, yaitu :

$\hat{Y}=0,493+0,561 X_{1}+0,019 X_{2}-0,125 X_{3}+0,220 X_{4}+0,202 X_{5}$

Peubah $X_{1} \mathrm{~s} / \mathrm{d} \mathrm{X}_{5}$ dinyatakan memiliki pengaruh terhadap $\mathrm{Y}$, apabila nilai nyata $t$ hitung kurang dan sama dengan 0,05 . Sesuai dengan hasil olahan data yang diperoleh, maka model regresi dapat diinterpretasikan sebagai berikut :

1) Nilai koefisien konstanta adalah 0,493 , maka bila nilai peubah independen $X_{1} \mathrm{~s} / \mathrm{d}$ $X_{5}$ adalah sama dengan nol, maka peubah dependen $(Y)$ bernilai 0,493 .

2) Peubah $X_{1}$ (product) memiliki tingkat nyata $(\alpha) 0,000$ menunjukkan peubah product memiliki pengaruh nyata terhadap citra TELKOM Speedy. Nilai koefisien regresi 0,561 dan memiliki pengaruh positif terhadap $Y$.

3) Peubah $\mathrm{X}_{2}$ (service) memiliki tingkat nilai nyata 0,776 menunjukkan peubah service tidak memiliki pengaruh terhadap citra TELKOM Speedy. Nilai koefisien regresi 0,019 dan memiliki pengaruh positif terhadap $Y$.

4) Peubah $X_{3}$ (channel) memiliki tingkat nilai nyata 0,161 menunjukkan peubah channel tidak memiliki pengaruh terhadap citra TELKOM Speedy. Nilai koefisien regresi $-0,125$ dan memiliki pengaruh negatif terhadap $Y$.

5) Peubah $X_{4}$ (promotion) memiliki tingkat nilai nyata 0,050 menunjukkan peubah promotion memiliki pengaruh terhadap citra TELKOM Speedy. Nilai koefisien regresi 0,220 dan memiliki pengaruh positif terhadap $Y$.

6) Peubah $X_{5}$ (brand) memiliki tingkat nilai nyata 0,013 menunjukkan peubah brand memiliki pengaruh terhadap citra TELKOM Speedy. Nilai koefisien regresi 0,202 dan memiliki pengaruh positif terhadap citra TELKOM Speedy.

Identifikasi peubah CEM yang paling berpengaruh dapat dilihat dari tabel Coefficients kolom Unstandarded Coefficients yang paling besar. Tiga (3) peubah $X$ yang memiliki pengaruh nyata terhadap $Y$ adalah $X_{1}, X_{4}$ dan $X_{5}$, dengan nilai koefisien masing-masing $0,561,0,220$ dan 0,202 . Koefisien regresi $X_{1}$ lebih besar daripada $X_{4}$ dan $\mathrm{X}_{5}$, sehingga dapat dinyatakan bahwa peubah $\mathrm{X}_{1}$ (product) memiliki pengaruh paling dominan terhadap citra TELKOM Speedy.

Hasil Uji $\mathrm{F}$ menunjukkan peubah independen secara bersama-sama berpengaruh terhadap peubah dependen, karena nilai nyatanya lebih kecil dari 0,05 (Nilai 0,000), maka model regresi peubah CEM secara bersama-sama berpengaruh nyata terhadap citra TELKOM Speedy.

Nilai uji $\mathrm{t}$ dapat dilihat dari nilai nyata pada masing-masing peubah independen dibandingkan taraf nyata yang digunakan $(0,05)$. Dari lima peubah $X$ yang diidentifikasi 
hanya tiga (3) peubah CEM yang berpengaruh terhadap citra TELKOM Speedy, yaitu peubah product, promotion dan brand.

Uji hipotesis digunakan untuk melihat pengaruh peubah CEM terhadap citra Telkom Speedy secara bersama-sama dan parsial.

a. Uji secara bersama-sama

Hipotesis yang diusulkan adalah Ho = Tidak terdapat pengaruh faktor-faktor CEM secara bersama-sama terhadap citra Telkom Speedy dan $\mathrm{H}_{1}=$ Terdapat pengaruh Faktor-faktor CEM secara bersama-sama terhadap citra Telkom Speedy. Hasil pengolahan data menunjukkan nilai nyata uji $\mathrm{F}$ adalah 0,000 lebih kecil dari nilai alpha 0,05 , sehingga tolak $\mathrm{Ho}$, atau terima $\mathrm{H}_{1}$.

b. Uji secara parsial

Hipotesis yang digunakan adalah $\mathrm{Ho}=$ Tidak terdapat pengaruh Peubah $\mathrm{X}$ terhadap citra Telkom Speedy dan $\mathrm{H}_{1}=$ Terdapat pengaruh Peubah $\mathrm{X}$ terhadap citra Telkom Speedy.

1) Nilai nyata $X_{1}(0,000)$ lebih kecil dari alpha 0,05 , sehingga tolak Ho dan terima $H_{1}$.

2) Nilai nyata $X_{2}(0,776)$ lebih besar dari alpha 0,05 , sehingga terima Ho, atau tolak $H_{1}$.

3) Nilai nyata $X_{3}(0,161)$ lebih besar dari alpha 0,05 , sehingga terima Ho, atau tolak $H_{1}$.

4) Nilai nyata $X_{4}(0,050)$ lebih kecil dan sama dengan alpha 0,05 , sehingga tolak Ho, atau terima $\mathrm{H}_{1}$.

5) Nilai nyata $X_{5}(0,013)$ lebih kecil dari alpha 0,05 , sehingga tolak Ho, atau terima $H_{1}$

\section{Kesimpulan}

Faktor-Faktor CEM pada PT TELKOM Kandatel Bekasi terdiri dari product, service, channel, promotion dan brand. Produk layanan Telkom Speedy terdiri dari tujuh paket, yaitu Paket Mail, Paket Chat, Paket Family, Paket Load, Paket Game, Paket Executive, Paket Biz dan Speedy PrePaid. Service bagi pelanggan adalah pemberian informasi dan registrasi, instalasi produk, pelayanan gangguan, penanganan keluhan dan pemutusan layanan yang dapat diperoleh di Plasa TELKOM. Pelayanan gangguan dapat disampaikan dengan menghubungi call center 147. Pada faktor channel, pelanggan dapat memperoleh Speedy dengan mendatangi Plasa TELKOM terdekat, di samping adanya kemudahan bagi pelanggan untuk melakukan proses pembayaran melalui ATM, Bank, Kantor Pos, dan Plasa TELKOM. Promosi yang biasa dilakukan di PT TELKOM Kandatel Bekasi antara lain, Open Table dan Pameran, Door to Door atau Personal Selling, Penyebaran Brosur, Kemitraan dengan Media di Bekasi, Kerjasama dengan Toko-Toko Komputer, Direct Mail, Merchandise dan paket diskon. Pada faktor brand, Speedy merupakan merek layanan akses internet yang memberikan keunggulan dari sisi kecepatan akses.

Dari analisis regresi linear berganda didapatkan 68,8\% peubah CEM dapat menjelaskan peubah citra TELKOM Speedy, uji $\mathrm{F}$ menunjukkan peubah CEM secara bersama-sama berpengaruh terhadap citra Speedy, serta uji t menjelaskan product, promotion dan brand berpengaruh secara nyata terhadap citra Telkom Speedy. Pada penelitian ini didapatkan koefisien beta product adalah yang terbesar $(0,561)$, maka peubah ini memiliki pengaruh paling dominan terhadap citra Telkom Speedy. Rekomendasi yang dapat diberikan kepada PT TELKOM Kandatel Bekasi adalah 
meningkatkan mutu dari layanan Speedy, terutama pada kecepatan akses (prioritas) bagi pelanggan dalam menggunakan Speedy, disamping mempertahankan dan meningkatkan service bagi pelanggan dalam setiap aspek seperti pemberian informasi, instalasi, penanganan keluhan dan gangguan dan pemutusan; pada aspek promotion menyesuaikan informasi yang diberikan pada saat promosi dengan kenyataan yang dialami pelanggan.

\section{Daftar Pustaka}

[APJII] Asosiasi Penyelenggara Jasa Internet Indonesia. 2009. Perkembangan Jumlah Pelanggan dan Pemakai Internet (Kumulatif). Asosiasi Penyelenggara Jasa Internet Indo-nesia, Jakarta

Kotler, P. and K.L. Keller. 2006. Marketing Management. Pearson Education Inc., New Jersey.

Nugroho, B.A. 2005. Strategi Jitu Memilih Metode Statistik Penelitian Dengan SPSS. Penerbit Andi, Yogyakarta.

Schmitt, B.H. 2003. Customer Experience Management: A Revolutionary Approach to Connecting With Your Customer. John Wiley \& Sons Inc. Hoboken, New Jersey.

Telkom. Tentang Telkom. http://www. telkom. go.id. [23 Januari 2010]

Umar, H. 2002. Metode Riset Bisnis. PT. Gramedia Pustaka Utama, Jakarta.

Wasesa, S.A. 2006. Strategi Public Relation. PT Gramedia Pustaka Utama, Jakarta. 